\begin{tabular}{ccc}
\hline & International Journal of Engineering \& Technology, $7(2.13)(2018) 46-50$ \\
SPC & International Journal of Engineering \& Technology \\
Website: $w w w . s c i e n c e p u b c o . c o m / i n d e x . p h p / I J E T$ & Research Paper \\
\hline
\end{tabular}

\title{
Patriotism and solidarity in the west and in Russia
}

\author{
Yury Grigoryevich Volkov ${ }^{1}$, Anna Vladimirovna Vereshchagina ${ }^{2}$, Anatoly Vladimirovich Lubsky ${ }^{3}$, \\ Viktoriya Olegovna Vagina ${ }^{4}$, Ivan Viktorovich Gubarev ${ }^{5}$
}

*Corresponding author E-mail: ugvolkov@sfedu.ru

\begin{abstract}
The article considers the peculiarities of the formation and development of patriotism and solidarity in the West and in Russia. The nature of these phenomena is revealed from the point of view of their socio-cultural and historical dependence. The article analyzes the prospects for the emergence of civil patriotism in Russia in the context of solidarity practices as a way to strengthen the state-civil identity and unity of all the nations in modern Russia. Given the existing differences in the development of patriotism and social solidarity in the West and in Russia, as well as the sociocultural foundations for the formation of civil patriotism in the context of solidarity practices, civil engagement and moral responsibility of citizens to the civil community are singled out as a determining condition
\end{abstract}

Keywords: Patriotism; Civil Patriotism; State Patriotism; Solidarity; Solidarity Practice; West; Russia.

\section{Introduction}

The current actualization of the discourse about patriotism and solidarity in the world is due to localization, in the frameworks of which national communities are able to reconstruct their history and identity. Civil patriotism, which is formed in the context of solidarity practices, often acts as a basis of this reconstruction since "the aspiration to a solidary activity as a positive form of social participation is associated with the sense of patriotism". Discourses about patriotism and solidarity in the West and in Russia are variable in nature and filled with different connotations depending on the assessment of certain events in Russia or abroad, on the trajectory of the intellectual tradition of these phenomena study in different countries and scientific schools. Discursive practices in the study of patriotism and solidarity in the West and in Russia, as a rule, reflect the nature of the contradictions and problems arising in the space of really developing patriotic and solidarity practices. In this regard, of particular interest is the comparative study of patriotism and solidarity in their correlation with real and discursive practices that have developed in the West and in Russia.

\section{Review of scientific literature}

In the modern Russian discourse, the concept of patriotism represents a composition of the most diverse value, ideological, social, political, cultural and moral interpretations. In this regard patriotism is considered as value, ideology, national idea, socialization mechanisms, social attitude, political resource, political practice, way of self-determination and self-identification, moral quality, sense of love for the country, component of civil culture, basis of civil identity [1-4]. At the same time, various typologies of patriotism are offered: jingoism - hostile to everything foreign; hurraypatriotism - loud, flashy and vociferous; conservatory - suspicious of everything new; rhetorical and declarative, authentic and abstract; public, civil and military; imperial, state and ethnic.
One of the most important tasks of foreign discursive practices is to consider the issue of the link between patriotism and nationalism and interpretation of the concept of patriotism in historical context. In foreign discourse, there are both positive and negative interpretations of patriotism, which distinguish true and false, good and bad patriotism. The research practices also distinguish constitutional and civil patriotism. In the context of the united Europe, the discourse practices, called europatriotism, become relevant. At the same time, the supporters of European integration advocate for the European patriotism based on the construction of European identity, values and organizational principles of the EU. However, since patriotism in Europe has traditionally been associated with the national government, the opponents of europatriotism were the adherents of euroscepticism [5-8].

The discourse also focuses on the issues related to the interpretation of the concept of solidarity in sociology history, social psychology and modern research practices. At the same time, researchers note that sociology actually began with the discussion of the idea of solidarity in society [9]. However, the fate of this idea was then extremely intricate: the periods of the rise and decline of interest in it were constantly alternating, and the very notion of solidarity was then marginalized and disappeared, then again returned to scientific discourse. In particular, there is now an increased interest in the solidarity which sometimes is interpreted as "a concentrated expression" and (or) a synonym for social life or as "a borderline concept, located on the verge of science, morality, law or policy". This allows scientists to talk about the diversity of solidarity as of a social practice, moral injunctions or emotional state. Recently, the scientific discourse has used the concept of civil solidarity as the basis of social integration [10], [11].

Thus, various aspects of patriotism and solidarity have already been studied within the framework of various scientific disciplines and paradigmatic grounds. However, patriotism and solidarity have not yet become the subject of holistic scientific interest, as a result, the holistic concept of patriotism and solidarity in Russia and the West has not yet formed. 


\section{Research methodology}

Overcoming disciplinary unilateralism and paradigmatic limitations requires the development of a multidimensional methodological construct for the scientific study of patriotism and solidarity in the West and in Russia within the framework of the neoclassical model of scientific research based on a critical, constructive-realistic, synthetic style of scientific thinking. The representatives of this scientific research model, considering scientific dialogue as a discursive social reality modeling, recognize that epistemological filters, mediating the interpretation of their objects play an important role in research practices. Proceeding from this, they believe that patriotism and solidarity as social realities exist objectively, but the scientific knowledge of them depends not only on the social reality itself, but also on those cognitive "prisms" through which researchers look at patriotism and solidarity and interpret the scientific facts obtained during their study [12-14].

The difficulties in developing a multidimensional methodological construct for the scientific study of patriotism and solidarity in the West and in Russia are due to the fact that there are different ideas about them in the discourse. This implies the operationalization of patriotism and solidarity notions by identifying their objective values. In this regard, it should be noted that in discursive practices, patriotism is, on the one hand, the diversity of judgments about patriotism, on the other - the cognitive field of competition associated with the production of scientific knowledge within the framework of various paradigmatic grounds. The Russian social philosophers give priority to the axiological, identification and ontological approaches, within the framework of which patriotism is regarded as the spiritual heritage of a person; basic spiritual value; love for motherland; willingness to work for the good of a country and its people, act of self-determination and self-identification of an individual and a nation, the natural essence of a person. In the historical and political science and sociology, along with the axiological one, the constructivist paradigm plays an important role, within the framework of which patriotism is viewed as the result of social construction with the help of the symbolic capital of power. At the same time, in the historical discourse patriotism is often regarded as a national idea, basic design of national consciousness, tool of ideological influence. In political science, patriotism is interpreted both as a way of identification, as a value, and as a national idea, as well as a political tool aimed at changing social and political reality. Sociological discursive practices in the study of patriotism use integrative approach, from the methodological standpoint of which patriotism appears, first, as a value that ensures the existence of society as a sociocultural community and civil nation; second, as a result of constructivist influences and constructive form of social self-determination; third, as a political construct and instrument of political management; fourth, as the main component of citizenship, civil culture, civil identity (in this aspect patriotism is considered as civil patriotism). As part of an integrative approach patriotism appears as the unity of patriotic feelings, knowledge and active participation of social actors in various kinds of social and work activities. Sometimes, from the standpoint of this approach, patriotism is viewed as a guarantor of national security, taking into account its socialization, mobilization, identification and solidarity potentials. An important aspect that unites almost all the areas of the scientific study of patriotism is the activity component - to love the motherland means, among other things, to take certain actions, deeds that would contribute to the preservation of the cultural heritage and the prosperity of the motherland and its people.

From the positions of the activity approach, the concept of patriotism is closely connected with solidarity practices. Therefore, some researchers believe that solidarity is a "special type of social interaction in which the moral duty translates resource identity into real activity, highlighting the transpersonal preference". In connection with this, one of the methodological problems associated with the study of solidarity is the issue of the correlation between solidarity as a "fact" and solidarity as a "debt".

Scientific discourse gives various answers to this question: some scientists, deducing the ethics of solidarity from actual solidarity, postulate moral prescriptions based on discursive judgments. At the same time, the adherents of liberal deontology defend the principle of the communicative genesis of solidarity as rooted in discursive practice and focused on the individual. However, their opponents communitarists - advocate for restoring the moral authority of the community in the era of social life individualization.

Other scholars believe that solidarity as a real phenomenon does not at all mean a moral duty and there is a moral obligation to be solidary. As a result, some researchers emphasize that "social science, separating the factual representation of solidarity from the normative one, cannot and should not be completely freed from the notion of what is due. It is only the fact that in the scientific study, firstly, the matter must be separated from the due, secondly, the latter must be based on the first, and not vice versa".

In historical retrospect, it is possible to identify the affective, conventional and reflexive forms of solidarity. Affective solidarity, which developed in traditional societies in the context of close social relations (neighborhood, kinship, family), is immediate-personal by nature. Conventional solidarity, which developed in the modern era on the basis of common social interests and values that unite social groups or communities, is socially-mediate, particularexclusive in nature. Reflexive solidarity, which developed in the era of late modernism in the context of globalization and the growth of cultural pluralism, is aimed at overcoming the affective and conventional solidarities, it is universal, being the basis of an ideal communicative community integrity.

It should be noted that social solidarity is based, first of all, on general not only discursive but also active social subjectness, which makes it possible to discuss and harmonize social interests and values, as well as implement institutional solidarity practices based on these interests and values. Cognitive-regulatory basis of solidarity actions are primarily the principles of social justice and social trust. In this regard, the cumulative concept of social solidarity was developed in the format of late modernism. It is based on the notion that, firstly, "the description of solidarity in terms of interpersonal (inter-subjective) relationship is the recognition of the individual in question as an equal and worthy interaction partner"; secondly, "a society that can be described in terms of solidarity is based on an equitable distribution of the chances of its subjects for recognition", and thirdly, "an equitable order of recognition is a prerequisite for social unity and solidarity".

\section{The research results}

Patriotism in the West and in Russia. As a term that has become the subject of intellectual reflection, patriotism appears in the early 18th century in England, where it quickly began being widely used by politicians who evaluated it on a simple dichotomous scale, "to be a patriot is good, not to be a patriot is bad" that initially placed it in an activity paradigm that demands from the patriot to perform certain socially useful actions from the viewpoint of certain public groups. Meanwhile, in a similar to patriotism semantic context, but without referring to this lexical structure, the evaluation of special relationship with the country, state, nation, religion and monarch took its shape in the period of antiquity. This was the time when the main trends, which subsequently led to the emergence of two main varieties of modern patriotism - civil and state -, arose.

Civil patriotism, as a social phenomenon, is associated with the peculiarities of the civil society of polis type that arose in ancient Greece. The peak of the manifestation of patriotic feelings was the feat of three hundred Spartans, who died for the independence of their homeland. But in general, the patriotic feelings of then Greek, localized on the love for his policy, pride of belonging to it and responsibility towards it, were experienced quite sharply.

Unlike civil, state patriotism was originally based on the imperial idea, and appeared in the practice of political relations, when Rome ceased to be an ordinary state of polis type and transformed into a huge empire in the course of conquests. Each empire is characterized by centrifugal tendencies, and the less economic, cultural, legal, social grounds for unity are, the stronger they are. Therefore, in 
this regard the main task for the imperial establishment of Rome is the need to find artificial, that is, created in the course of purposeful reflection, universal identification marks common to all. Such common identity is created within the framework of emperor's cult idea According to the idea, the empire was to become a single civil community united not only by a common market and citizenship, which generously began being granted in the provinces, but also by a single religion supposedly capable of becoming the spiritual core for the awakening imperial solidarity feelings: pride, responsibility, love, superiority over the others. This idea turned out to be unfounded at that particular time, but, thanks to 325 religious castling, which replaced the emperor's cult for Christianity, gave rise to a fertile spiritual ground for the growth of almost all European empires in the Middle Ages, many of which existed until the end of the First World War. It was they which transmitted the idea of state patriotism to the public consciousness through vertical interrelations, that is, from power to society, making it very relevant for long in Russia, Germany, Austria, partly in France and Spain, where the society was spiritually tied with the state on the basis of the broad masses' conviction in the missionary meaning of this connection, manifesting in the conscious need to transfer their values to other peoples and to involve them through joint efforts of people and authorities in the orbit of its cultural influence.

In the modern Western scientific tradition, the social essence of patriotism shifted to some middle point, which is located between state patriotism and civil patriotism. This point cannot be considered equidistant from the state and civil society, since horizontal interrelations are still the basis of Western patriotism. They function on the basis of a strong, well-functioning civil society. Given the foregoing, the patriotism of the Western world could be defined as civil nation patriotism, but it is not completely homogeneous. The European Union can be given as an example. For many EU citizens, such an understanding of patriotism becomes a transitional stage to the attainment of a common European identity and, consequently, the formation of pan-European patriotism, when each EU citizen feels responsibility not only for some selected countries (France, Germany, Spain and so on. n.), but for the whole Europe, establishing a common European house construct as a leading idea, object of patriotic feelings application. This articulates the need for universal European values, the absence of which at this stage is recognized as one of the most serious problems of European integration. Disagreements about values cause unsteadiness and instability of the pan-European patriotism that, in turn, activates the regressive processes in the frameworks of which certain European population strata identify the concept of civil nation with the idea of nationalism and state sovereignty. For example, Germany, and especially France are now experiencing very significant rise in nationalist sentiment, the scientific community increased their calls for the need to return to the concept of state sovereignty, indicating the haste of the current integration processes. At this stage, particularly with regard to Brexit and excessive politicization of the process of EU expansion into the east, it is difficult to say which of the trends will prevail in the future. And this means that it is difficult to predict how the Western patriotism will be developing in the future.

Russian patriotism is of completely different social origin. The idea of polis civil community had almost no impact on its formation. It is not only due to the fact that Russia was on the periphery of Europe and did not know the reception of Roman law and did not experience its renaissance. Civil horizontal interrelations did not form largely due to the fact that the main vector of the vital processes, creating the basic framework of social cohesion, were based on vertical interrelations, directed from the authorities to the society. Historically, the power in Russia was the main manager of social wealth and the initiator of the most significant undertakings. As for social strata, they were to some extent less active in terms of their capacity for social action. It is no accident that the social structure itself was not so profoundly differentiated, as in Western Europe, existing as a more or less homogeneous substance, especially from the perspective of the legal relationship to the state.
In these circumstances, Russia formed state patriotism, which very organically united the feelings of love, pride, responsibility and superiority over others, expressed in relation to the state-homeland, which, in turn, accumulated inside itself the concept of nationality, religion and personal loyalty to the monarch. Everything was organized most syncretically: religion (Orthodoxy) defines national identity, and the state cannot be imagined without the personal loyalty to the monarch since it was paternalistic in nature. Taken together, this created a single platform serving an inductor for the emergence and maintenance of patriotic feelings. Therefore, the Russian patriotism did not need the support of civil forces, which existed in the system of horizontal interrelations within the society. Its initiator was the state. And while the subjects of the Russian Empire identified themselves with the figure of the king (the emperor), acting as a defender of true religion and champion of supreme justice ranked above classes and parochial interests, patriotism meant the involvement of every citizen into the Russian civilization.

Equally strict and unambiguous judgments should not be applied to the modern Russian patriotism, despite the well-known historical determinism. It, like Western patriotism, cannot be uniquely determined. First of all, because the syncretism of patriotic feelings and social conditions, which gave rise to it, collapsed. Orthodoxy as an ideological axis forming civilization identity and autocracy, by means of which all the state authorities were personified, were excluded from the values of the Russian mentality. To date, Russia has developed a multi-dimensional space of patriotism, including those of its varieties, as ethnic, religious, regional, corporate and civil. However, the desire to prevent the break-up of social ties, actualized by the lack of a stable civil society, makes the Russian political elite attempt to revive the very state patriotism. To this end, the authorities are not trying to destroy existing horizontal interrelations, many of which have developed in 1990s during the building of traditional interrelations of vertical type, using for this purpose brightly colored, emotionally rich patriotic rhetoric, appealing mainly to the heroic past of the Russian state. This kind of practice has shown its viability and effectiveness that resulted in an increase in feelings of patriotism and substantial increase in President Putin's personal rating in the last few years. With a view to preserving the paternalistic attitude of Russians to the head of the state in the system of basic values, this result can hardly be recognized as surprising. As surprising, rather, must be regarded the longtime disdain of the resource by the authorities.

The result of the efforts made by the Russian authorities in the area of patriotic education should be the formation of the Russian nation on the basis of a sustainable public-civil identity. This identity should be based on civil patriotism, which is in its turn essentially based on solidarity practices which allows overcoming numerous contradictions on grounds of inter-ethnic and inter-confessional relations.

Solidarity in the West and in Russia. The decisive factor for the cessation of solidarity practices in Western Europe is considered to be one of its unique features never before found in any of the regions of the world: power in the medieval Western Europe were divided into two sources - political and economic. Administrative and political power was located in the castles while the economic one was developing in the form of bourgeois municipalities essentially alien to feudal suzerainty-vassalage. Over time, this led to the war between cities and feudal aristocracy (13-15th centuries) that only increased the special nature of the civil solidarity in European urban ecumene, making it more consolidated. Having achieved the independence, then cities were already the resource (especially the tax one), which provide public authorities the possibility to implement their policies. Naturally, the state tried to put them under its control, but these attempts faced some difficulties and in some countries, in England for example, they completely failed, triggering the revolution which undermined the position of the monarchy. Thus, the urban strata won administrative independence, which was transformed from the point of view of modern terminology into municipal authority. This factor can be considered as the leading feature in the development of the solidarity of the Western type. The 
ability of socium to self-organization is currently considered to be the source of the stimulating activity in all Western European countries.

It can hardly be called a coincidence that in French and German science and political practice, various concepts of solidarism - an ideology, located between liberalism and social democracy - became very important. From the first it adopts freedom being strongly delimited with an apology for individualism; from the second - the idea of the social responsibility of the state, but rejects the concept of class struggle. The basic postulate of solidarity is the creation of a society of citizens socially responsible towards each other.

In general, it should be noted that solidarity in modern Western countries can be represented as a subjective capacity to organize itself into some common community based on a common group identity. However, this understanding of solidarity is deeply historical in its essence, because it lacks the main idea of real solidarity practices. In fact, group solidarity is not yet general social solidarity, as the values on which it is based, can cause intergroup conflict. The most clearly it is implemented as a class antagonism generating acute manifestations of instability in society. The modern Western world built general social solidarity through the values universal for all social actors. The presence of universal civil values has made it possible to move beyond the boundaries of solidarity communities outlined by the markers of group identity and integrate the totality of social groups as a single societal community united by common to all notions of social solidarity. This, to a certain extent, is a social ideal for the Western world, far from being a utopia. For a long period of time such understanding of solidarity as a social reality was obstructed by already mentioned class antagonism, which generated a lot of contradictions in the relationship between social groups. However, the construction of a consumer society, development of civil society organizations and middle class growth helped to solve a number of problems, which had prevented achieving a consensus. Meanwhile, the consensus is an important condition for building an intergraded value space since mutual recognition of a value as mutual by at least two actors is inherently a consequence of a conventional act. Therefore, currently leading trend in the development of solidarity practices in the Western world is not just group forms of solidarity that since the Middle Ages are a reality in the system horizontal interrelations in urban communities, but the general social solidarity of all the social groups that sets the European countries on the wide path of civil nation construction and the European community on the path of the creation of a "common house" for all the peoples of Europe. The latter is still very far from being complete, as European values themselves are under development. But there are some prospects, the feasibility of which is challenged because of parallel amplifying aspiration of European societies to revive national identity in contrast to a common European identity. The both trends are equivalent, and therefore, both scenarios are possible in the future.

Social essence of the solidarity practices formed in Russia cannot be understood outside the context of the organizational role performed by the Russian state. It is referred, above all, to paternalism as a phenomenon, rooted in deep historical past of Russia. This phenomenon defines the current development of Russia.

It cannot be said that solidarity practices in Russia were formed and regulated only through vertical interrelations channels, but they were definitely priority and, most importantly, in the presence of state expediency suppressed all the other forms of civil activism contradicting the goals of the state. This was the situation during the formation of a centralized state in Russia. In the imperial period, despite a number of progressive reforms developing the initiative of citizens associations, only the external facade of society corresponded to the Western standards. Nothing changed in Soviet Russia since the authorities gained ideologically grounded right to govern all the forms of civil life, at the same time suppressing any nonsanctioned initiative on the part of public organizations. Therefore, all solidarity practices were built through a clear vertical hierarchy from Octobrists to Pioneers and Komsomol before joining the Communist Party, which had, in its turn, its own hierarchy.
Things began changing only after the collapse of the USSR. Civil society, which, in turn, can be formed only under conditions of political freedom, providing ideological pluralism and any form of dissidence and civil initiative, begins serving as a social matrix for establishing solidarity relations. This was made possible for the first time in the history of our country since the early 1990-ies. Now this period is often estimated to be negative. The clichéd phrase "turbulent 90-ies" came into general use. But it is undeniable that the era was the first real attempt of the Russian society to take the path of social self-organization without the involvement of public authorities. And this is the way of gaining social solidarity in a system of horizontal interrelations.

For a long period the development of civil society as the basis of "self-organized" social solidarity was positioned as a priority task of Russian social development. It was stipulated by the need to build democracy in the shortest possible time and the needs of integration in the European world, but now the vectors of social problems have changed a little. In the context of crisis in relations with the Western world and given the intention of the Russian authorities a priority should be placed on ensuring social stability and national security. The issue of restoring the former role of the state in regulating social relations becomes the major one. In many ways, the Russian authorities are trying to establish so-called controlled democracy, manageable civil society and, therefore, social solidarity, the image of which is controlled to meet the challenges of the state scale, that is, again, within the vertical interrelations, so typical of the socio-cultural practices of the Russian society.

"Social solidarity" is created as an empirical matrix for the formation of the Russian nation, united by universal civil values, but this process is no longer boosted mainly on the initiative of the society, as in Western Europe, but directly by the Russian state. The reason is obvious - the Russian civil society as a set of self-governing and independent from government organizations turned to be underdeveloped.

\section{Summary}

The analysis leads to the conclusion that Western and Russian social solidarity and patriotism developed and established in different ways. They are of different origin, largely derived from the nature of patriotism, formed in the West and in Russia.

Patriotism as a phenomenon of the spiritual and moral order associated with a deep sense of love for the country and belonging to its culture, history and people is formed at the level of either horizontal or vertical interrelations. In the first case, they are the product of social self-organization and generate a number of different social identities capable of competing with each other and weakening the social stability. Patriotism in such conditions is of natural origin, because it serves for the emotional injection of rather conscious interests and values of particular social groups. It is the western path of development. In the second variant patriotism is initiated by the authorities for achieving certain objectives related, as a rule, to strengthening state organization, stabilization and legitimation of political order, resulting in the formation of a single identity, patriotism common to all. In both cases, the basis for formation and development is active start, with the slight difference that in the first case it is initiated by the citizens included in solidarity communities, while in the second - by the state, taking control over society self-identification process and solidarity practices implementation. Obviously, only the first option reflects the true nature of civil patriotism in the context solidarity practices, while the second, inherent in Russian society, has more to do with emotional parameters of interactions between citizens and the state.

Civil activity, the purpose of which is to protect citizens from life risks and ensure citizens' participation in public affairs in the presence of high moral responsibility towards the nation as a civil society in which ethnic, religious, cultural and other features and differences smooth over mature national identity and national pride, underlies civil patriotism in the context solidarity practices. In other 
words, emotion- and activity-colored ties with nation as united people, expressed in solidarity practices, symbolize the ethno-cultural, religious and other identities important for citizens, but not competing with local civil identity.

The formation of civil patriotism in this solidarity context is one of the possible and promising options in terms of the implementation of nation-building and strengthening public-civil identity in Russia. The model of civil historic-cultural patriotism, taking into account the mental peculiarities of formation and development of statehood and citizenship in a society as part of civilizational trajectory of its development seems to be the most suitable tool for this.

\section{Acknowledgement}

Article is written within the framework of the state task (Ministry of Education and Science of the Russian Federation), project No. 28.3486.2017 / PCh «Civil patriotism in the formation and development of solidarity practices in the South of Russia: resource potential and the conditions for its utilization

\section{References}

[1] Article is written within the framework of the state task (Ministry of Education and Science of the Russian Federation), project No. 28.3486.2017 / PCh «Civil patriotism in the formation and development of solidarity practices in the South of Russia: resource potential and the conditions for its utilization."

[2] Robertson R., Knondker H. Discourses of globalization: Preliminary Considerations // International, Sociology. 1999. Vol. 13. No 1. P. 25-40.

[3] Volkov Yu. G. Joint Activity in the Russian society: creative practice // Sociological studies. No. 2017. 2. P. 45.

[4] Kuznetsov I. M. Variability of discourses about patriotism in the everyday consciousness of Russians // Vast'. 2016. No. 7. P. 164

[5] Patriotism // Encyclopedie Universale. [Electronic resource]. URL: fracacademic.com/59454/patriotism; Patriot // New Websters Dictonary of the Engliscy Language. New Delhi, 1989. P. 1088; Patriotismus // Duden. Das Herkunftswörterbuch: Etymologie der deutschen Sprache. Der Duden in zwölf. Bänden. 3. Auflage. Band 7. Leipzig; Wien; Zürich: Dudenverlag, Mannheim, 2001. S. 594

[6] Lutovinov V. I. Modern Russian patriotism: its nature, characteristics, main directions // International electronic scientific review. Studia Humanitatis. No. 2. 2013. [Electronic resource]. URL: http://st-hum.ru/content/lutovinov-vi-sovremennyy-rossiyskiy-patriotizm-sushchnost-osobennosti-osnovnye-napravleniya; Bakhtin A. G. Historical foundations of Russian patriotism // Proceedings of Mari State University. No. 3. 2014. pp 9-14; Magaril S. A. Meanings of patriotism - historical transformations // Sociological studies. No. 1. 2016. Pp. 142-151; Haliy I. A. Patriotism in Russia: classification experience // Sociological studies. No. 2. 2017. pp 67-74; Lubsky A. V. Civil patriotism: patriotism on compatibility and citizenship in the Russian society // Gumanitariy Yuga Rossii. No. 1. 2017. pp 42-59.

[7] Kudrya A. D. The notion of "patriotism", its essence and types. [Electronic resource]. URL: https://superinf.ru/view_helpstud.php?id=3284; Epstein M. Types of patriotism. [Electronic resource]. URL: https://snob.ru/profile/27356/blog/83932+T-

[8] Viroli M. For Love of Country: An Essay on Patriotism and Nationalism. Oxford: Oxford University Press, 1997; Nairn T., James P. Global Matrix Nationalism Globalism and Terrorism. London; New York: Pluto Press, 2005; Beck U., Beck-Gernsheim E. Global Generations and the Trap of Methodological Nationalism for a Cosmopolitan Turn in the Sociology of Youth and Generation // European Sociological Review. 2009. No. 25 (1). P. 25-36.

[9] Blatberg Ch. From Pluralist to Patriotic Politics: Putting Practice First. Oxford: Oxford University Press, 2000; Cohen J., Nussbaum Thakurdesai PA, Kole PL \& Pareek RP (2004), Evaluation of the quality and contents of diabetes mellitus patient education on Internet. Patient Education and Counseling 53, 309-313. M.C. For Love of Country: Debating the Limits of Patriotism. Boston: Beacon Press, 1996; Patriotism // Reprinted in Patriotism / Ed. by I. Primoratz. New York: Humanity Books, 2002.

[10] Dustin Gr. Patriotism and Poetry in Eighteenth-Century Britain, Cambridge: Cambridge University Press, 2005; Ackermann B. Ein neuer Anfang fur Europa. Nach dem utopischen Zeitalte. Berlin Siedler Verlag, 1993.
[11] Kronenberg V. «Verfassungspatriotismus» im vereinten Deutschland // Aus Politik und Zeitgeschichte. Nr. 28. 06.07.2009.

[12] John McCormick. Europeanism. Oxford: Oxford University Press, 2010; Keulman K., Koós A.K. European Identity: Its Feasibility and Desirability. Lanham MD: Lexington Books, 2014

[13] EU-Scepticism vs. Euroscepticism. Re-assessing the Party Positions in the Accession Countries towards EU Membership // EU Enlargement: Current Challenges and Strategic Choices / Ed. by L. Finn. Bruxelles: Peter Lang. 2011; European Sources Online Information Guide: Euroscepticism. Cardiff:Cardiff University Press. 2015.

[14] Ursulenko K. Social solidarity: development of the concept in the history of sociology and modern interpretations // Sociology: Theory, Methods, and marketing. Kiev: The National Academy of Sciences of Ukraine, 2009. No. 1. P. 151-155. 